\title{
Blood oxygen stores of olive ridley sea turtles, Lepidochelys olivacea are highly variable among individuals during arribada nesting
}

\author{
by
}

B. Gabriela Arango

\author{
A thesis submitted to \\ Sonoma State University \\ in partial fulfillment of the requirements \\ for the degree of \\ MASTER OF SCIENCE \\ in \\ Biology
}

Committee members:

Dr. Daniel E. Crocker, Chair

Martha Harfush Meléndez, M.S.

Dr. Nicholas R. Geist

Date: 07-12-2019 


\section{Copyright 2019}

By B. Gabriela Arango 


\section{Authorization for Reproduction of Master's Thesis}

I grant permission for the print or digital reproduction of this thesis in its entirety, without further authorization from me, on the condition that the person or agency requesting the reproduction absorb the cost and provide proper acknowledgement of authorship.

Date: 07-12-2019

Name: B. Gabriela Arango 


\title{
Blood oxygen stores of olive ridley sea turtles, Lepidochelys olivacea are highly variable among individuals during arribada nesting
}

\author{
Thesis by \\ B. Gabriela Arango
}

\begin{abstract}
Sea turtles are mostly pelagic, air-breathing divers that can become neritic during nesting season. Sea turtles dive with a full lung of air and these $\mathrm{O}_{2}$ stores are supplemented by $\mathrm{O}_{2}$ stored in blood. Olive ridley sea turtles exhibit polymorphic nesting behavior; mass nesting behavior called arribada, where up to 25,000 turtles will nest at once, and solitary nesting behavior. As mostly pelagic and highly migratory species, we hypothesize that newly arrived turtles, nesting in arribadas, will exhibit increased blood oxygen stores as compared to solitary nesting towards the end of the season, where turtles have likely become neritic. We measured blood volume and associated variables to estimate total blood $\mathrm{O}_{2}$ stores including hematocrit and blood hemoglobin content. There were no significant differences in mean values between nesting periods, but arribada nesting individuals were more variable than those performing solitary nesting. Mass specific plasma volume was relatively invariant among individuals but mass specific blood volume and blood oxygen stores varied widely, 2-fold and 3-fold, respectively. Blood $\mathrm{O}_{2}$ stores represented $32 \%$ of total body $\mathrm{O}_{2}$ stores. Under typical mean diving conditions of $26^{\circ} \mathrm{C}$ and high levels of activity, blood stores confer $\sim 14 \mathrm{~min}$ to aerobic dive times and are likely critical for the long duration, deep diving exhibited by the species. Individual differences in blood $\mathrm{O}_{2}$ stores strongly impact estimated aerobic dive limits and may constrain the ability of individuals to respond to changes on ocean climate.
\end{abstract}

MS Program: Biology

Sonoma State University

Date: 07-12-2019 


\section{Acknowledgment}

My research would have been impossible without the aid and support of my family, friends, coworkers, lab mates and committee members. Additionally, I am profoundly grateful to Dr. Horacio Merchant and José Alejandro Marmolejo Valencia from

Universidad Autónoma de México (UNAM), Stacey Pelton from McNair Scholars and to the Centro Mexicano de la Tortuga (CMT) personnel. 


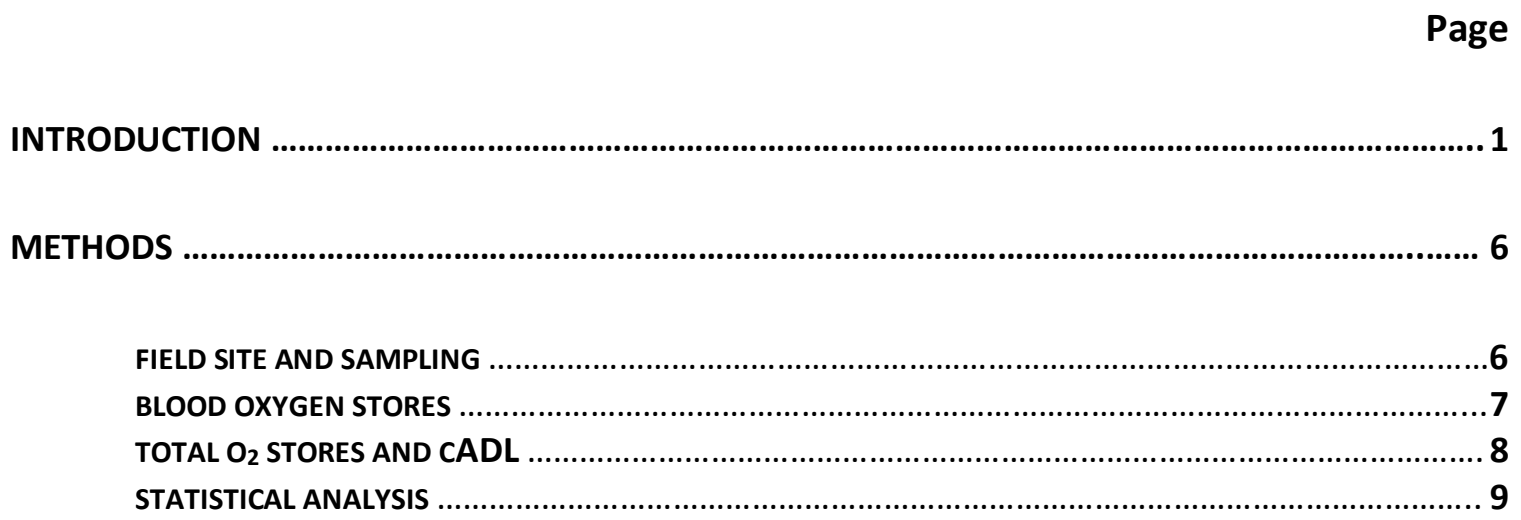




\section{List of Tables}

Table 1. Values from arribada nesting, solitary nesting and their averages. Values presented are least square means \pm standard error mean. $\mathrm{M}_{\mathrm{b}}=$ body mass; $\mathrm{Hb}=$ hemoglobin; $\mathrm{Hct}=$ hematocrit; $\mathrm{MCHC}=$ mean corpuscular hemoglobin concentration; $\mathrm{PV}=$ plasma volume; $\mathrm{BV}=$ blood volume. ${ }^{*}$ denotes significant differences between the nesting periods $(p<0.05)$.

Table 2. Mean blood values for $L$. olivacea from this study and other species of sea turtles. $\mathrm{Hb}$ values are expressed as $(\mathrm{g} / 100 \mathrm{~mL}$ blood). 


\section{List of Figures}

Figure 1. Marine Protected Area La Escobilla. Field site located in the Pacific Ocean in Oaxaca, Mexico. Figure by E. Albavera.

Figure 2. Plasma volume increased with body mass. Open circles denote arribada nesting and closed circles denote solitary nesting $\left(r^{2}=0.68, p<0.0001\right)$. Plasma volume was calculated from dilution of Evan's Blue dye.

Figure 3. Blood volume increased weakly with body mass. Open circles denote arribada nesting and closed circles denote solitary nesting $\left(r^{2}=0.16, p=0.06\right)$. Blood volume was calculated as PV $\left[(100-\mathrm{Hct})^{-1}\right]$.

Figure 4. Mass specific blood oxygen stores calculated from plasma volume and Hct. Stores were more variable during the arribada nesting period (Levene's test, $p=0.04$ ).

Figure 5. Estimated $c A D L$ from total $\mathrm{O}_{2}$ stores $(A)$ and blood $\mathrm{O}_{2}$ stores $(B)$ at water temperatures ranging from $21.5^{\circ} \mathrm{C}-30.0^{\circ} \mathrm{C}$ and $0-100 \%$ activity during the dive. Diving metabolic rate was estimated using Equation 1 from Williams et al., 2019. 


\section{INTRODUCTION}

Air-breathing diving animals display a variety of anatomical, physiological, and behavioral adaptations that allows them to increase their time underwater used for foraging, migrating, mating and predator avoidance. These animals maximize time at depth through the use of aerobic metabolism and enhance dive durations through increased body $\mathrm{O}_{2}$ stores (Kooyman, 1989; Ponganis, 2011; Ponganis \& Williams, 2016). Total body $\mathrm{O}_{2}$ stores are dependent on several variables, including diving lung volume, blood volume, hemoglobin $(\mathrm{Hb})$ concentration, muscle mass, and myoglobin $(\mathrm{Mb})$ concentration (Ponganis \& Williams, 2016). While extensive research has been done on $\mathrm{O}_{2}$ stores and the physiology of breath-hold diving in endotherms, less is known about individual and inter-specific variation in diving $\mathrm{O}_{2}$ stores in marine reptiles, including sea turtles (Berkson, 1966; McMahon, Bradshaw, \& Hays, 2007; Wells \& Baldwin, 1994).

Sea turtles are important apex predators in marine ecosystems and have complex predator-prey interactions that help shape food webs. Additionally, sea turtles play important roles in almost every ocean ecosystem, from nesting beaches, internesting habitats, epipelagic habitats, and benthic habitats (Hawkes, Broderick, Godfrey, \& Godley, 2009; Heithaus, 2013; Spotila, 2004; Wallace et al., 2011). Out of the five main hazards for marine turtles (climate change, fisheries bycatch, take, coastal development, pollution and pathogens), fisheries bycatch is the biggest threat, followed closely by impacts of climate change (Wallace et al., 2011). Understanding the factors that limit sea turtle breath-hold capacity is important to predicting their ability to respond to potential changes in water temperature and prey distributions that result 
from climate change (Yang et al., 2019) and the potential for mortality due to incidental by-catch in fishing nets, the main anthropogenic threat to sea turtles (Lewison et al., 2013; Polovina et al., 2004; Polovina, Howell, \& Balazs, 2003; Wallace et al., 2011; Williard, 2013; Yang et al., 2019).

The diving and movement behaviors of free-ranging sea turtles have been well investigated using data loggers and satellite telemetry (e.g. Arendt et al., 2012; Bradshaw, McMahon, \& Hays, 2007; Ceriani, Weishampel, Ehrhart, Mansfield, \& Wunder, 2017; Chambault et al., 2016; Dodge, Galuardi, Miller, \& Lutcavage, 2014; Gaos et al., 2012; Hays \& Hawkes, 2018; Hays, Hobson, Metcalfe, Righton, \& Sims, 2006; Hochscheid, 2014; Howell et al., 2010; Okuyama et al., 2012; Polovina et al., 2004; Polovina, Howell, Parker, \& Balazs, 2003; Richardson et al., 2013; Swimmer et al., 2006). Sea turtles spend about $90 \%$ of their time submerged and without breathing (Williard, 2013). Diving time of sea turtles varies with the purpose of their dive (Heithaus, 2013). Dive duration in internesting turtles increases with depth (e.g. Hays et al., 2000; Hays, Metcalfe, \& Walne, 2004; S. Hochscheid, Godley, Broderick, \& Wilson, 1999), especially during resting dives, where depth is modulated by the volume of inspired air (e.g. Hays et al., 2004; Minamikawa et al., 2000; Yasuda \& Arai, 2009). During active dives, dive duration is influenced by activity (Okuyama et al., 2012) and strong impacts of activity levels on rates of oxygen consumption and heart rates have been measured in captivity (Enstipp et al., 2011; Williams et al., 2019). As ectotherms, body temperature and rates of oxygen consumption are also influenced by water temperature in the Cheloniidae sea turtles (Spotila, O’Connor, \& Paladino, 1996). 
A key difference among marine divers is whether or not they make use of their lung $\mathrm{O}_{2}$ stores. The deepest divers, including many marine mammals, dive below the depth of lung collapse and prioritize tissue $\mathrm{O}_{2}$ stores. Some deep divers, like phocid seals, avoid respiratory gas exchange at depth by diving after exhalation (Ponganis \& Williams, 2016). Other marine divers, such as sea turtles and penguins dive following inhalation (S. C. Wood, Gatz, \& Glass, 1984), and lung oxygen stores are an important component of diving metabolism (McDonald \& Ponganis, 2013). In sea turtles, the lung serves as the major oxygen store during diving and limited measurements of tissue oxygen stores have suggested similar values to non-diving vertebrates (Lutz \& Bentley, 1985; Lutcavage et al., 1990, 1992; Ponganis, 2015). For this reason, the literature in sea turtles have deemphasized measurements of blood $\mathrm{O}_{2}$ stores with most published values from small samples, captive animals or juveniles. To our knowledge, data for the calculation of total blood oxygen stores in the sea turtle, olive ridley (Lepidochelys olivacea) have not been reported in the literature, except for one small sample $(n=2)$ of blood volume measurements (Thorson, 1968).

One approach to assess the breath-hold capacity of air-breathing divers is the aerobic dive limit (ADL). ADL is an estimation of physiological and energetic constraints on the dive durations of air-breathing diving animals (Costa, Gales, \& Goebel, 2001; Ponganis, Meir, \& Williams, 2011; Williams, Meir, \& Ponganis, 2011). ADL is the maximum amount of time an animal can spend underwater before the product of anaerobic respiration, lactate, rises beyond resting levels in their blood (Butler, 2006; Costa et al., 2001; Kooyman, 1989). However, establishing a direct and precise ADL 
value through measurements of blood lactate is difficult to achieve. Therefore, ADL is calculated as CADL, which is the ratio of the total usable amount of oxygen $\left(\mathrm{O}_{2}\right)$ stored in the body $\left(\mathrm{O}_{2}\right.$ from blood, muscles and lungs) to the diving metabolic rate (energy budget of an animal) (Ponganis et al., 2011; Ponganis \& Williams, 2016). Some studies have reported CADL values of sea turtles that use only estimates of lung $\mathrm{O}_{2}$ store. Highly variable values of CADL have been reported for leatherback (Dermochelys coriacea), loggerhead (Caretta caretta), flatback (Natator depressus) and hawksbill (Eretmochelys imbricata) (Hochscheid et al., 2007; Williard, 2013). No cADL estimates have been reported for olive ridley turtles.

Several recent observations suggest the importance of including blood $\mathrm{O}_{2}$ stores in the consideration of breath-hold ability in sea turtles (Chambault et al., 2016; Hochscheid et al., 2007; McMahon et al., 2007; Wells \& Baldwin, 1994). Biologging data have revealed deep, long duration dives in some species that may exceed the capacity of lung $\mathrm{O}_{2}$ stores to support aerobic metabolism (Chambault et al., 2016; McMahon et al., 2007). Lung collapse may occur in deep diving turtles due to their compliant respiratory system on the deepest dives evident in biologging studies (Lutcavage, Lutz, \& Baier, 1989; Tenney, Bartlett, Farber, \& Remmers, 1974). Together, these findings suggest that contribution of tissue $\mathrm{O}_{2}$ stores to aerobic limits may be critical for some dives. Further, recent studies on the sympathetic autonomic control of pulmonary shunts to limit decompression injuries in sea turtles may limit access to lung $\mathrm{O}_{2}$ stores in some contexts and the lung stores are accessed using intermittent perfusion (GarcíaPárraga et al., 2018; Portugues et al., 2018). 
Olive ridley turtles exhibit two types of nesting behavior, solitary nesting and arribada nesting (Spotila, 2004). Solitary nesting occurs throughout the year and females are widely spaced, returning at varying internesting intervals (Pritchard, 2007; Spotila, 2004). During arribada nesting, thousands of females synchronize themselves to nest together, during the third-quarter moon for a 2-7 day arribada period from JuneFebruary (Bernardo \& Plotkin, 2007; Ramirez Acevedo, Martinez Blas, \& FuentesMascorro, 2012). Although many beaches worldwide along 32 different countries are suited for solitary nesting (Spotila, 2004), only a few are suited for arribada nesting, located in Costa Rica (Ostional and Nancite), India (Gahirmatha) and Mexico (La Escobilla) (Bernardo \& Plotkin, 2007; Spotila, 2004). The world main arribada beach is located in the marine protected area of "La Escobilla", on the Pacific side in Oaxaca, Mexico (Valverde et al., 2012). Despite being the most abundant species of sea turtle, olive ridleys have undergone a $30-50 \%$ reduction in their historical global population size. There is only one major nesting site left in Mexico, La Escobilla, and two minor ones, Ixtapilla and Morro Ayuta (Albavera Padilla, 2007). As consequence, the Mexican population is classified as endangered (Abreu-Grobois \& Plotkin, 2008).

Olive ridley are active pelagic predators, hunting on $77 \%$ of their dive durations, and can occupy different habitats according to their population (Chambault et al., 2016; McMahon et al., 2007). Foraging grounds have been associated with the high presence of micronekton biomass and their carnivorous generalist diet includes crustaceans, cephalopods, fishes and jellyfishes (Chambault et al., 2016). This large foraging area makes them more susceptible to fisheries by-catch. Despite being the smallest sea 
turtle, olive ridleys exhibit long duration, deep dives when foraging pelagically. Mean dive duration for a large sample of adult females was $46 \mathrm{~min}$. Dives as long as $200 \mathrm{~min}$ (3.3 hours) and as deep as $300 \mathrm{~m}$ have been reported (Chambault et al., 2016;

McMahon et al., 2007; Polovina, Howell, \& Balazs, 2003; Stabenau \& Heming, 1994).

Our primary objectives were to 1) measure plasma and blood volume and estimate tissue oxygen stores in large sample of free- ranging adult female olive ridley sea turtles during nesting; 2) compare blood oxygen stores and associated variables between the arribada and solitary nesting periods; 3) estimate CADL for the sampled olive ridley sea turtles at a range of water temperatures and activity levels and compare these estimates to published diving behavior. As a mostly pelagic and highly migratory species, we hypothesize that newly arrived turtles, nesting in arribadas, will exhibit an increased CADL as compared to solitary nesting towards the end of the season, where turtles have likely become neritic.

\section{METHODS}

\section{Field site and sampling}

All animal handling procedures were approved by the Sonoma State University IACUC and performed under collecting permit SGPA/DGVS/12915/16. Samples were exported for laboratory analysis to Sonoma State University under exporting/importing permits CITES MX88143 and CITES 19US85728C/9. Nesting olive ridley females were sampled at the marine protected area of La Escobilla, Oaxaca, Mexico (15 $47^{\prime} \mathrm{N}$; $96^{\circ} 44^{\prime}$

W; Figure 1) during solitary nesting in February $2017(n=10)$ and during the arribada in 
November, $2017(n=13)$. Handling and sampling were performed while the turtle was nesting, after digging the nest, since this is when females enter a 'trance-nesting period' (Dutton, 1996); and we were less likely to disrupt nesting. None of the females were disturbed from their nesting, nor returned to the sea without laying their eggs.

Females sampled during solitary nesting were weighed using a hand-held scale ( \pm $0.1 \mathrm{~kg})$. Because of an equipment failure it was not possible to weigh the females sampled during arribada nesting. For these females, mass was estimated using a regression from published data on olive ridley morphometrics (Espinoza-Romo et al., 2018; $n=59$, mass $\left.=-47.44+1.13 \times S C L, r^{2}=0.70, p<0.001.\right)$. This equation predicted the mass of the turtles that were weighed with a mean error of $4 \%$.

All blood samples were collected from the cervical vein (Dutton, 1996; Mettee, 2014). An initial blood sample was taken into a heparin Vacutainer tube to measure hematocrit and hemoglobin values. Females were injected with Evan's Blue dye ( 1 $\mathrm{mg} / \mathrm{kg}$ ) and plasma volume was calculated after corrected for hemolysis (El-Sayed, Goodall, \& Hainsworth, 1995). Three sub sequential blood samples were taken at approximately 7-minute post injection intervals. Syringes were calibrated gravimetrically to determine precise injection volume. Blood samples were kept on ice for $\mathbf{2 0}$ minutes until centrifuged at the field site. All plasma samples were frozen after centrifugation at $-20^{\circ} \mathrm{C}$ until laboratory analysis.

\section{Blood oxygen stores}

Hemoglobin $(\mathrm{Hb})$ concentration, hematocrit $(\mathrm{Hct})$, plasma volume $\left(\mathrm{V}_{\mathrm{p}}\right)$ and mean corpuscular hemoglobin concentration $(\mathrm{MCHC})$ were determined for each animal. 
Hematocrit was calculated by standard microcentrifugation, averaging three values for each sample. Absorbance of Evans Blue dye in the plasma was determined at 624 and $740 \mathrm{~nm}$. Values at $740 \mathrm{~nm}$, which do not absorb blue, were used to calculate the blank optical density at $624 \mathrm{~nm}$ and correct for hemolysis and precipitate (Foldager \& Blomqvist, 1991). Values from serially collected Evans Blue samples were logtransformed, fit to a regression line, and the $y$-intercept was used to determine the instantaneous dilution volume by comparing to a serial dilution of the injectate (ElSayed et al., 1995). Blood volume $\left(V_{B}\right)$ was calculated as $V_{P}(1-H c t / 100)$, where $V_{P}$ is absolute plasma volume. Hb concentration was measured using the cyanmethemoglobin method (Sigma D5941, St. Louis, MO). Mean corpuscular Hb concentration (MCHC) was calculated as $100 \mathrm{Hb} \mathrm{Hct}^{-1}$. Total available blood oxygen stores were calculated assuming one-third of blood was arterial and two-thirds of blood was venous (Lutz \& Bentley, 1985), 95\% and 80\% saturation, respectively (Lutcavage, Bushnell, \& Jones, 1990) and a $\mathrm{Hb}$ oxygen carrying capacity of $1.34 \mathrm{ml} \mathrm{O}_{2} \mathrm{~g}^{-1}$.

\section{Total $\mathrm{O}_{2}$ stores and $C A D L$}

Muscle $\mathrm{O}_{2}$ stores were estimated assuming $22 \%$ of mass is muscle (Lutz \& Bentley, 1985) and a Myoglobin (Mb) concentration of $3.1 \mathrm{mg} \mathrm{g}^{-1}$ muscle tissue. Lung $\mathrm{O}_{2}$ stores were estimated using an allometric equation for lung volume (Hochscheid et al., 2007) and assuming the inspired air was $17.4 \% \mathrm{O}_{2}$ (Berkson, 1966). Oxygen consumption rate was estimated using the equation developed for captive loggerhead turtles that incorporates water temperatures and activity levels (Williams et al., 2019). Finally, cADL

was calculated as the total body oxygen stores divided by the oxygen consumption rate. 
We calculated CADL for each individual turtle at $100 \%$ activity and a mean water temperature of $26^{\circ} \mathrm{C}$, the average temperature recorded for free-ranging olive ridleys (Chambault et al., 2016). We visualized CADL for total $\mathrm{O}_{2}$ stores and for the contribution of blood $\mathrm{O}_{2}$ stores across a range of activities from $0-100 \%$ and water temperatures ranging from $18.7^{\circ} \mathrm{C}$ to $30^{\circ} \mathrm{C}$, the range of water temperatures encountered by freeranging olive ridleys (Chambault et al., 2016; McMahon et al., 2007).

\section{Statistical analysis}

Statistical analysis was performed using JMP Pro 14 (SAS Institute, USA).

Variables of interest were compared between the arribada and solitary nesting samples using two-sample t-tests with pooled or unequal variance. Unequal variance was assessed using Levene's test. Relationships to body mass were assessed using simple linear regression. Statistical significance was considered at $p=0.05$.

\section{RESULTS}

\section{Blood oxygen stores}

Values for olive ridleys' mass $\left(\mathrm{M}_{\mathrm{b}} \mathrm{kg}\right), \mathrm{Hb}\left(\mathrm{g} \mathrm{dL}^{-1}\right)$, $\mathrm{Hct}(\%), \mathrm{MCHC}\left(\mathrm{g} \mathrm{dL}^{-1}\right), \mathrm{V}_{\mathrm{P}}(\mathrm{mL}$ $\left.\mathrm{kg}^{-1}\right)$ and $\mathrm{V}_{B}\left(\mathrm{~mL} \mathrm{~kg}^{-1}\right)$ on wild nesting solitary females $(\mathrm{n}=10)$, wild nesting arribada females $(n=13)$ and their averages are presented in Table 1. Blood Hb did not vary between nesting periods $(p=0.14)$ but was more variable during the arribada period (Levene's test, $p=0.03)$. Hct was similar during the 2 nesting periods $(p=0.38)$. The variation in $\mathrm{Hb}$ content was unrelated to $\mathrm{Hct}(\mathrm{p}=0.33)$, due to individual differences in 
calculated MCHC. MCHC did not vary between nesting periods $(p=0.58)$ but was more variable during the arribada period (Levene's test, $p=0.03$ ).

Mean $V_{P}$ increased significantly with increased body mass $\left(V_{P}=28.3 *\right.$ mass + 795.4, $r^{2}=0.31, F_{1,21}=9.37 p<0.006$; Figure 2). $V_{p}$ was $5.4 \pm 0.4(S D) \%$ of body mass and this percentage was greater during the arribada period $(t=3.04, d f=21 p=0.006) . V_{B}$, calculated using $V_{P}$ and Hct was not related to body mass $(p=0.35$; Figure 3$)$. $V_{B}$ was 8.1 \pm 1.3 (SD) \% of body mass and this percentage did not vary between nesting periods ( $p=$ 0.17). Estimated mass specific blood $\mathrm{O}_{2}$ stores were $7.74 \pm 1.8(\mathrm{SD}) \mathrm{ml} \mathrm{O}_{2} \mathrm{~kg}^{-1}$. This value did not vary between nesting periods $(p=0.92)$, but was more variable during the arribada period (Levene's test, $p=0.008$; Figure 4).

\section{CADL and diving behavior}

CADL ( $\mathrm{min}$ ) from estimated total $\mathrm{O}_{2}$ stores was calculated for water temperatures ranging from $18.7^{\circ} \mathrm{C}-30.0^{\circ} \mathrm{C}$ (Chambault et al., 2016; McMahon et al., 2007) and for activity levels of $0-100 \%$ of the dive (Kinoshita, Fukuoka, Niizuma, Narazaki, \& Sato, 2018; Williams et al., 2019) (Figure 5A). At $26^{\circ} \mathrm{C}$, the mean temperature value encountered by olive ridley's during their post-nesting migration (Chambault et al., 2016), cADL ranged from $40.5 \pm 2.8 \mathrm{~min}$ to $85.8 \pm 5.9 \mathrm{~min}$ depending on activity levels. Blood oxygen stores represented $32.2 \pm 5.2 \%$ of estimated total body oxygen stores. Thus, blood $\mathrm{O}_{2}$ stores added $13.52 \pm 2.9$ to $27.9 \pm 6.2 \mathrm{~min}$ to aerobic dive times in $26^{\circ} \mathrm{C}$ water. In the coldest water $\left(18.7^{\circ} \mathrm{C}\right)$ and at rest ( $0 \%$ activity), blood $\mathrm{O}_{2}$ stores added $42.7 \pm 9.4$ min to aerobic dive times (Figure 5B). 


\section{DISCUSSION}

For a large sample of free-ranging nesting olive ridley sea turtles, blood volume was $7.6 \mathrm{ml} \mathrm{kg}^{-1}$ body mass and blood $\mathrm{O}_{2}$ stores were $7.2 \mathrm{ml} \mathrm{O}_{2} \mathrm{~kg}^{-1}$. This represents $\sim 32 \%$ of body oxygen stores when making standard assumptions on lung volume and muscle stores. These stores may represent a critical component of aerobic capacity on the longest and deepest dives exhibited by individuals of the species. Mass specific blood volume was similar to that reported for leatherbacks (7.7\%; Table 2) and was slightly higher than that reported previously for other chelonidae (6.6-6.7\%; Thorson, 1968). However, as previously reported, blood volumes were not remarkable when compared to terrestrial species (Thorson, 1968).

Mass specific blood volume and blood oxygen stores varied widely among individuals, 2-fold and 3-fold, respectively. Plasma volume was relatively invariant and most of these differences were due to variation in hematocrit, $\mathrm{Hb}$ and associated $\mathrm{MCHC}$ content. This wide individual variation in blood oxygen stores emphasizes the importance of physiological state to aerobic capacity and the value of having a large sample size for assessing capacity of a species. Hb concentrations decreased weakly with body mass, but the drivers of widely varying hematocrit and most of the variation in $\mathrm{Hb}$ content of blood is unknown. Large sample size studies of sea turtle hematology yield similarly wide ranges of Hct among individuals (e.g. (Lewbart et al., 2014; Rousselet et al., 2013; F. E. Wood \& Ebanks, 1984) and have demonstrated associations of Hct with stress, contaminant burdens, ectoparasites and tumor scores (García-Párraga et al., 2014; Keller, Kucklick, Stamper, Harms, \& McClellan-Green, 2004; Stamper et al., 2005; 
Work \& Balazs, 1999). A significant correlation between Hct and the straight carapace length of sea turtles has been previously reported (F. E. Wood \& Ebanks, 1984) but we found no relationship to mass or size in our study.

We compiled published body mass, $\mathrm{Hct}, \mathrm{Hb}$ content, $\mathrm{BV}$ and $\mathrm{MCHC}$ values for five species of sea turtles (Table 2). When compared to the other species, olive ridley sea turtle has the lowest $\mathrm{Hct}$ and $\mathrm{Hb}$ values. $\mathrm{MCHC}$ values were relatively consistent among other species, with the exception of the deep-diving $D$. coriacea. However, Lepidochelys kempii and L. olivacea are closely related to each other (Crawford et al., 2015) and as such, MCHC values are very close to each other. Given this relationship, it would be expected that both species will be well adapted to increase their diving time by the use of total blood oxygen stores. But this is not the case, as L. kempii has not been documented to exhibit such deep dives like L. olivacea. In fact, L. kempii exhibit the shallowest dives of all sea turtles, with the deepest recorded dive of $5.3 \mathrm{~m}$ (Williard, 2013). D. coriacea is the species that had the largest values of mass-specific blood volume, but this was expected since they are the deepest divers from all seven species (Robinson \& Paladino, 2015). What was most surprising was the striking similarity on $V_{B}$ values between $D$. coriacea $\left(7.7 \mathrm{ml} \mathrm{kg}^{-1}\right)$ and L. olivacea $\left(7.6 \mathrm{ml} \mathrm{kg}^{-1}\right)$ sea turtles. This supports previous observations of L. olivacea as being the second-deepest diver (300 m; Stabenau \& Heming, 1994) of all species of sea turtles after D. coriacea (1280 m; LópezMendilaharsu, Rocha, Domingo, Wallace, \& Miller, 2008). Blood $\mathrm{O}_{2}$ stores may be especially critical if pulmonary shunts are activated as part of the dive response to avoid decompression injuries on the deepest and longest dives (García-Párraga et al., 2018). 
Interestingly, olive ridley sea turtles newly calculated blood $\mathrm{O}_{2}$ stores are similar to those reported for the best avian divers, emperor penguins (Aptenodytes forsteri) (Ponganis et al., 2011), with blood stores representing $31 \%$ of body $\mathrm{O}_{2}$ stores.

We found no significant difference in blood $\mathrm{O}_{2}$ stores or associated variables between the two nesting periods. A previous study found that Hct is higher in migrating turtles compared to nesting values (Yang et al., 2019). This difference was thought to be due to conditioning effects from longer, deeper dives during the migratory phase. We found no similar evidence of conditioning between recently arrived arribada turtles and turtles that had spent several months in residence during internesting intervals. One possible explanation for this finding is that our sampled turtles are residents of La Escobilla - as it has been demonstrated that olive ridley populations differ widely in habitat use (Chambault et al., 2016; Polovina et al., 2004).

Although there were no significant differences between nesting periods, several measured variables were more variable during the arribada nesting. Females were heavier during arribada. $\mathrm{Hct}, \mathrm{Hb}, \mathrm{MCHC}$ and mass-specific blood $\mathrm{O}_{2}$ stores are all more variable during the arribada nesting. The underlying cause of this variability was not due to differences in mass and likely reflects physiological state. These differences may reflect differences in habitat use among the arriving turtles (i.e. migratory or resident). A recent study on transport stress in Kemp's ridley showed that the stress of transport increased variability in Hct in association with changes in corticosterone and glucose concentrations (Hunt et al., 2019). A study on different stress-responses between solitary and nesting females found that arribada nesting turtles exhibited slower 
elevation of corticosterone in response to a stress test but did not compare baseline levels (Valverde, Owens, Mackenzie, \& Amoss, 1999). Future studies should evaluate potential modulators of the increased individual variation seen during this nesting period.

Based on measures of diving behavior in olive ridley sea turtles, blood $\mathrm{O}_{2}$ stores are likely a critical component of aerobic respiration to many dives. Lung stores are similar among species, suggesting that diving differences might be most likely due to individual variation in blood $\mathrm{O}_{2}$ stores rather than in muscle stores, given low myoglobin constants across species; $4 \%$ of total body $\mathrm{O}_{2}$ stores (Berkson, 1966; Lutz \& Bentley, 1985; Stabenau \& Heming, 1994). Previous investigations reporting deep and long dive behaviors exhibited by olive ridley sea turtles (Chambault et al., 2016; McMahon et al., 2007; Polovina et al., 2004) demonstrated that $77 \%$ of dive time represents active foraging behaviors, and that some dives exceed the presumed depths of lung collapse ( $120 \mathrm{~m}$, Berkson, 1967). Our CADL estimates that incorporate blood stores of $\sim 41 \mathrm{~min}$ for dives with high levels of activity and at mean water temperatures as reported for foraging dives, suggesting that blood $\mathrm{O}_{2}$ stores provide $\sim 14$ min of dive time and are necessary to support the diving behavior on the majority of dives. Recorded average dive duration in olive ridleys is $\sim 46 \min$ (Chambault et al., 2016). All dives are likely aerobic as their short and invariant post-dive surface times do not suggest that turtles are incurring a lactate debt and use of pulmonary shunts to avoid decompression injury on some deep dives may further emphasize the importance of blood stores (GarcíaPárraga et al., 2018). 


\section{Conservation Implications}

Bycatch, the primary mortality threat to sea turtles, often results in death from drowning or signs of decompression sickness in $43 \%$ of incidental captures (GarcíaPárraga et al., 2014). The evidence for decompression injuries in incidentally captured turtles, emphasize the importance of modulation of lung perfusion during diving in sea turtles and the potential for loss of access to lung stores during all or parts of dives. Individual and interspecific variation in blood $\mathrm{O}_{2}$ stores may be an important factor in avoiding drowning when captured in fishing nets.

The primary determinant of rates of oxygen use in diving sea turtles is activity levels (Williams et al., 2019). However, given high rates of activity on most foraging dives, water temperature is also an important modulator of diving metabolism. Changes in water temperature due to global warming can directly affect ectothermic body temperature and lower breath-hold capacity. Based on our calculations a 1 degree change in mean water temperature reduces aerobic dive time by $\sim 6 \%$ at high activity levels. Further, changes in thermal structure, currents and prey distribution in response to climate change may require substantial alterations to diving behavior (Hawkes et al., 2009; Poloczanska, Limpus, \& Hays, 2010). Individual and interspecific variation in blood $\mathrm{O}_{2}$ stores may be a crucial component of enabling behavioral plasticity in response to these changes.

\section{CONCLUSION}

The first large sample study on blood $\mathrm{O}_{2}$ stores in olive ridley sea turtles revealed that these stores represent a critical component of total body $\mathrm{O}_{2}$ stores. Mass-specific 
blood volumes were similar to that reported for larger deeper diving leatherback sea turtles and appear to be essential to support the long duration diving behavior reported for olive ridleys. The wide individual variation in blood $\mathrm{O}_{2}$ stores has important implications for intraspecific variation in breath-hold ability. This variation was greater during the arribada nesting period due to increased variation in both hematocrit and $\mathrm{MCHC}$. High blood $\mathrm{O}_{2}$ stores may be a critical component of the behavioral plasticity needed to respond to changes in prey distribution, thermal structure and currents that result from climate change. 
Appendices 
Table 1. Values from arribada nesting, solitary nesting and their averages. Values presented are least square means \pm standard error mean. $\mathrm{Mb}_{\mathrm{b}}=$ body mass; $\mathrm{Hb}=$ hemoglobin; $\mathrm{Hct}=$ hematocrit; $\mathrm{MCHC}=$ mean corpuscular hemoglobin concentration; $\mathrm{PV}=$ plasma volume; $\mathrm{BV}=$ blood volume. ${ }^{*}$ denotes significant differences between the nesting periods $(p<0.05)$.

\begin{tabular}{|c|c|c|c|c|}
\hline & Arribada Nesting & $\begin{array}{l}\text { Solitary } \\
\text { Nesting }\end{array}$ & Average & Range \\
\hline $\mathrm{Mb}_{\mathrm{b}}(\mathrm{kg})$ & $34.9 \pm 1.3^{*}$ & $29.6 \pm 0.9$ & $32.6 \pm 1.0$ & $22.3-40$ \\
\hline $\mathrm{Hb}\left(\mathrm{g} \mathrm{dL}^{-1}\right)$ & $8.9 \pm 0.5$ & $9.7 \pm 0.2$ & $9.2 \pm 0.3$ & $6.0-12.9$ \\
\hline Hct $(\%)$ & $30.6 \pm 2.4$ & $32.9 \pm 0.8$ & $31.6 \pm 1.4$ & $18-50$ \\
\hline $\mathrm{MCHC}\left(\mathrm{g} \mathrm{dL}^{-1}\right)$ & $0.31 \pm 0.03$ & $0.30 \pm 0.01$ & $0.31 \pm 0.01$ & $0.18-0.43$ \\
\hline $\mathrm{PV}(\mathrm{mL})$ & $1768.1 \pm 44.8^{*}$ & $1506.5 \pm 43.6$ & $1654.4 \pm 41.5$ & \\
\hline $\mathrm{PV}\left(\mathrm{mL} \mathrm{kg}{ }^{-1}\right)$ & $5.1 \pm 0.1$ & $5.1 \pm 0.1$ & $5.1 \pm 0.4$ & $4.4-6.1$ \\
\hline $\mathrm{BV}(\mathrm{mL})$ & $2593.3 \pm 121.8^{*}$ & $2247.9 \pm 68.7$ & $2443.1 \pm 82.12$ & \\
\hline $\mathrm{BV}\left(\mathrm{mL} \mathrm{kg}^{-1}\right)$ & $8.4 \pm 0.1$ & $7.6 \pm 0.1$ & $8.1 \pm 0.1$ & $5.8-11.4$ \\
\hline $\begin{array}{l}\text { Blood } \mathrm{O}_{2}(\mathrm{~mL} \\
\left.\mathrm{kg}^{-1}\right)\end{array}$ & $7.8 \pm 0.6$ & $7.8 \pm 0.3$ & $7.8 \pm 0.4$ & $3.6-10.8$ \\
\hline
\end{tabular}


Table 2. Mean blood values for $L$. olivacea from this study and other species of sea turtles. $\mathrm{Hb}$ values are expressed as (g/100 mL blood).

\begin{tabular}{|c|c|c|c|c|c|c|}
\hline $\begin{array}{l}\text { Common } \\
\text { Name }\end{array}$ & $\begin{array}{l}\text { Body } \\
\text { Mass } \\
(\mathrm{kg})\end{array}$ & $\begin{array}{l}\text { Hct } \\
\text { (\%) }\end{array}$ & $\begin{array}{c}\mathrm{Hb} \\
\left(\mathrm{g} \mathrm{dL}^{-1}\right)\end{array}$ & $\begin{array}{c}\mathrm{MCHC} \\
\text { (Hb/Hct) }\end{array}$ & $\begin{array}{c}\text { Blood } \\
\text { volume (ml } \\
\left.\mathrm{kg}^{-1}\right)\end{array}$ & Reference \\
\hline Olive ridley & 31 & 32 & 9.2 & 0.29 & 7.8 & This study \\
\hline Kemp's ridley & 37.8 & 32 & 10.1 & 0.30 & 6.7 & $1,2,3$ \\
\hline Loggerhead & 35 & 41 & 9.8 & 0.24 & 6.7 & 1,4 \\
\hline Hawksbill & 24 & 39 & 9.6 & 0.24 & - & 5 \\
\hline Green turtle & 145 & 45 & 10.6 & 0.23 & 6.6 & 6,7 \\
\hline Leatherback & 300 & 39 & 15.6 & 0.40 & 7.7 & 8,9 \\
\hline
\end{tabular}


Figure 2. Marine Protected Area La Escobilla. Field site located in the Pacific Ocean in Oaxaca, Mexico. Figure by E. Albavera.

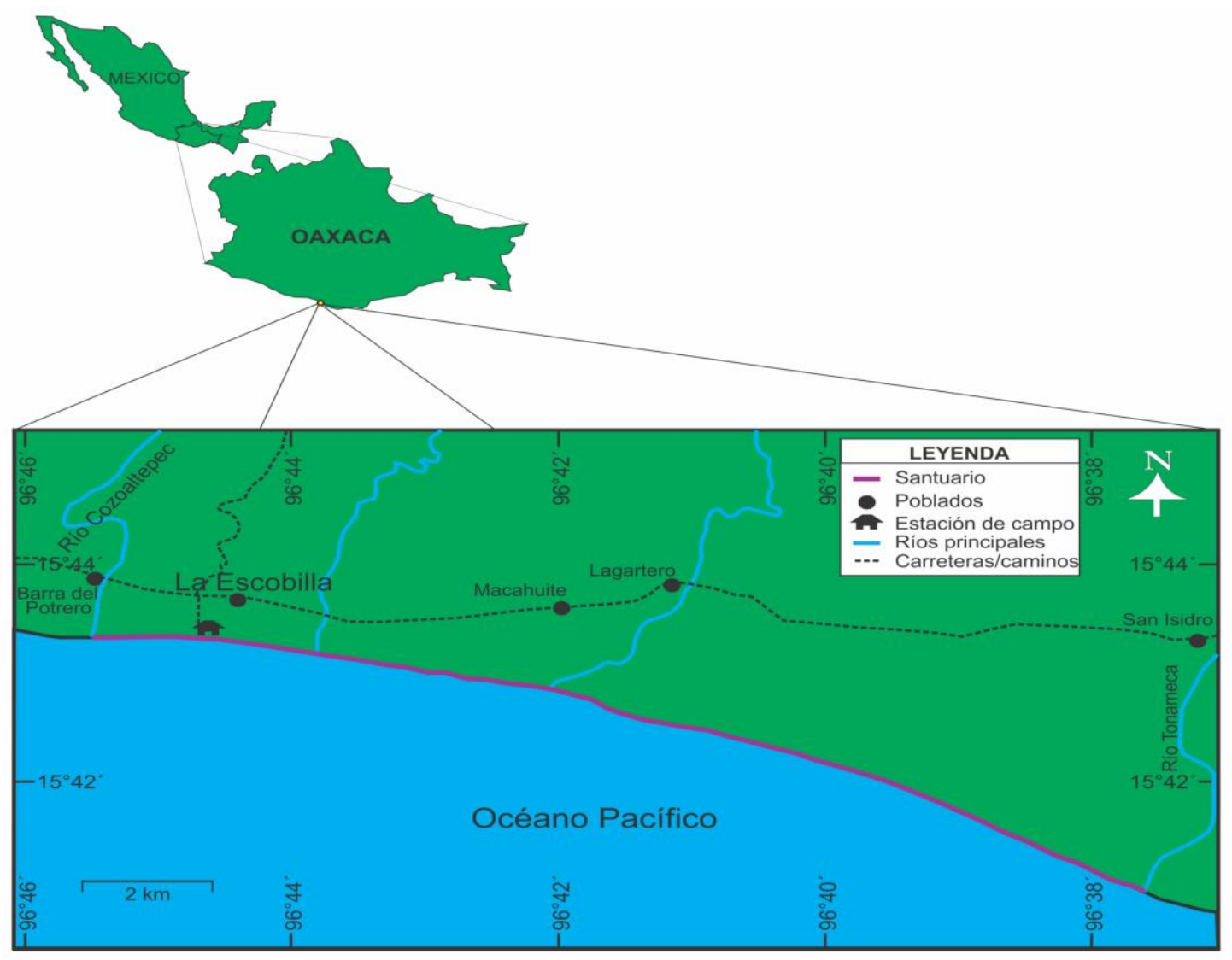


Figure 2. Plasma volume increased with body mass. Open circles denote arribada nesting and closed circles denote solitary nesting $\left(r^{2}=0.68, p<0.0001\right)$. Plasma volume was calculated from dilution of Evan's Blue dye.

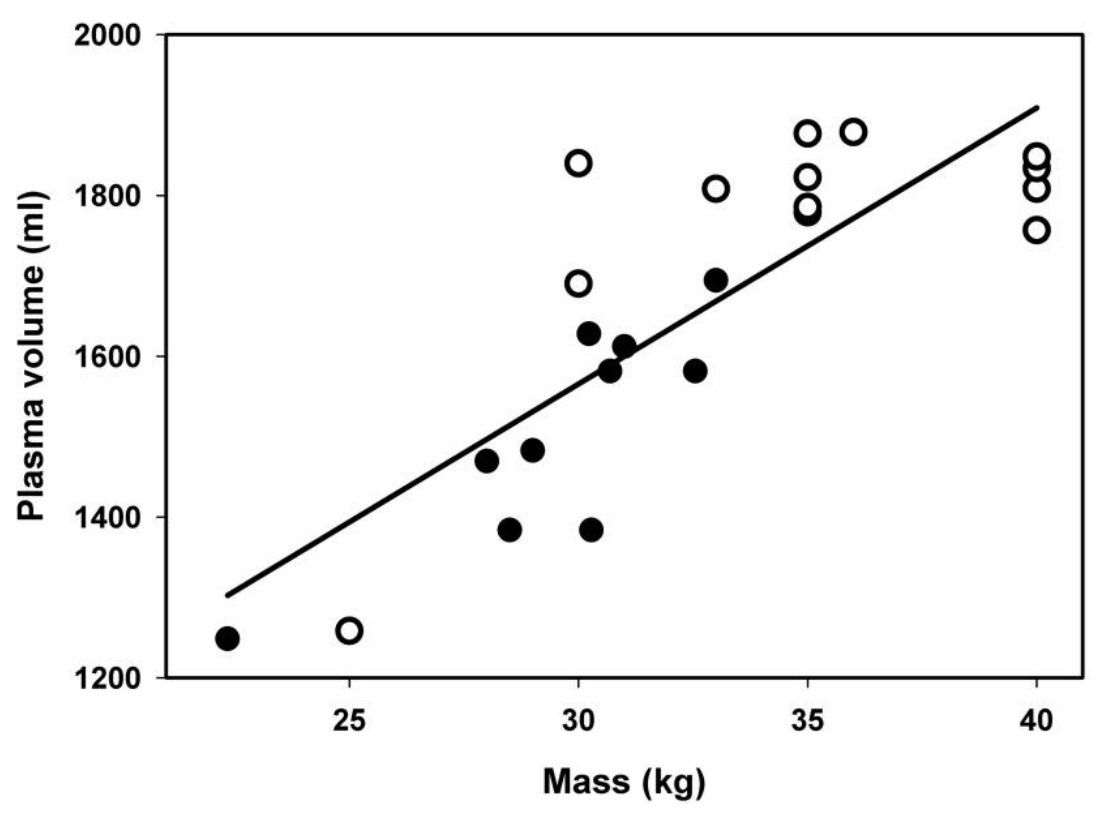


Figure 3. Blood volume increased weakly with body mass. Open circles denote arribada nesting and closed circles denote solitary nesting $\left(r^{2}=0.16, p=0.06\right)$. Blood volume was calculated as PV [(100 - Hct $\left.)^{-1}\right]$.

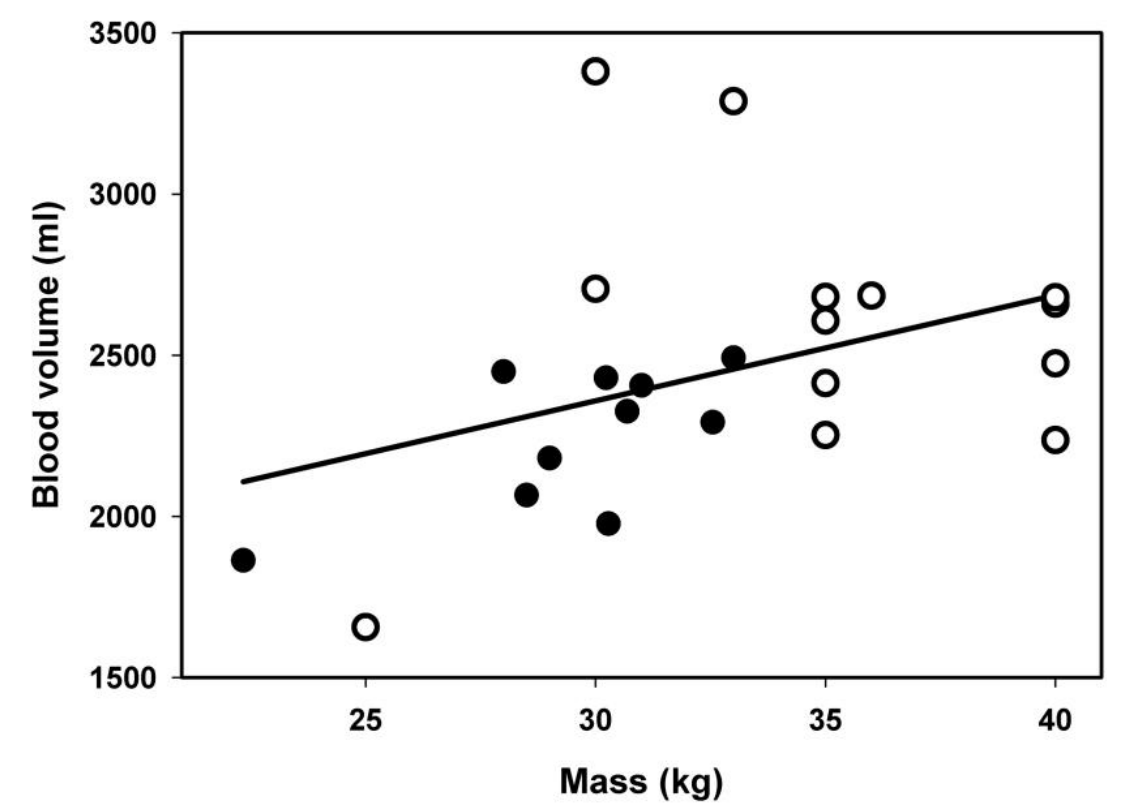


Figure 4. Mass specific blood oxygen stores calculated from plasma volume and Hct. Stores were more variable during the arribada nesting period (Levene's test, $p=0.04$ ).

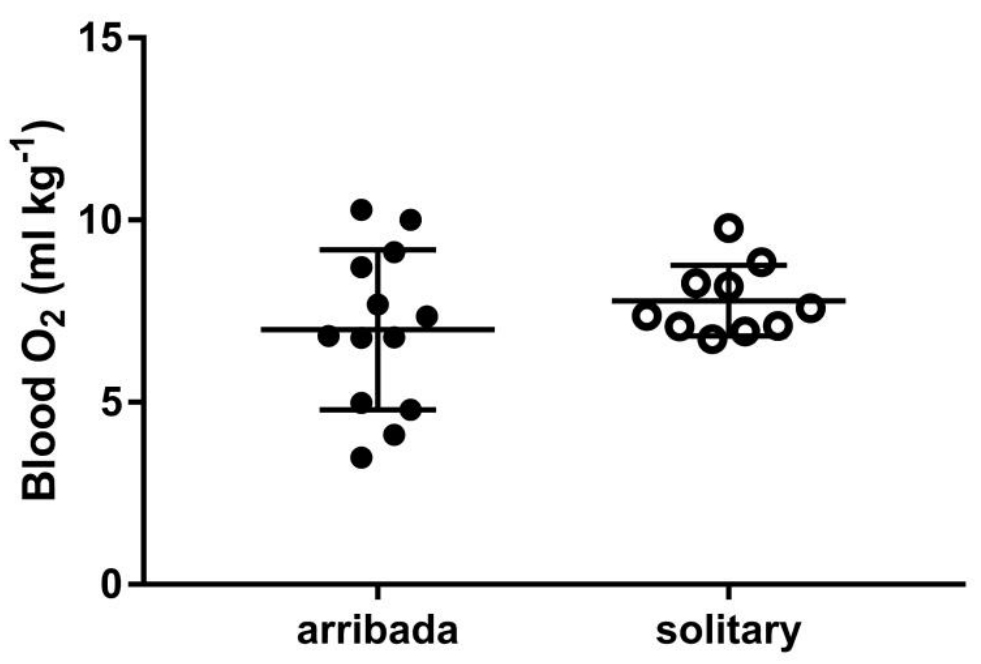


Figure 5. Estimated $c A D L$ from total $\mathrm{O}_{2}$ stores $(A)$ and blood $\mathrm{O}_{2}$ stores $(\mathrm{B})$ at water temperatures ranging from $21.5^{\circ} \mathrm{C}-30.0^{\circ} \mathrm{C}$ and $0-100 \%$ activity during the dive. Diving metabolic rate was estimated using Equation 1 from Williams et al., 2019.
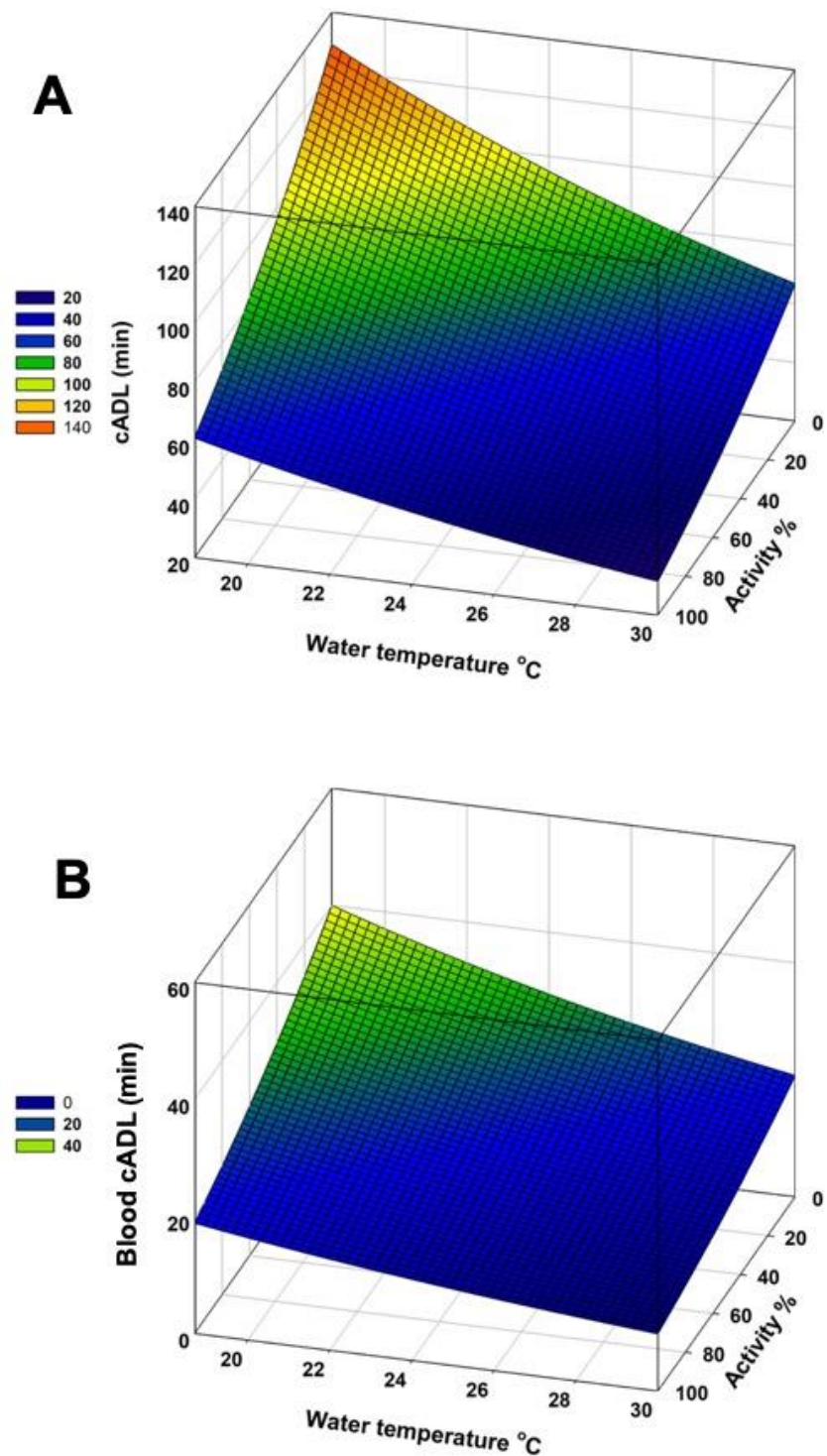


\section{REFERENCES}

Abreu-Grobois, F. A., \& Plotkin, P. T. (2008). Lepidochelys olivacea. The IUCN Red List of Threatened Species 2008: e.T11534A3292503. Retrieved June 27, 2019, from https://www.iucnredlist.org/species/11534/3292503

Albavera Padilla, E. (2007). Situación actual de la tortuga golfina (Lepidochelys olivacea) en playas de arribada del Pacífico Mexicano. In E. Carvajal Hinojosa, L. Rodríguez, L. Sarti Martínez, N. García Tellez, \& A. R. Barragán (Eds.), Reunión Nacional sobre Conservación de Tortugas Marinas (pp. 42-45). Veracruz.

Arendt, M. D., Segars, A. L., Byrd, J. I., Boynton, J., Schwenter, J. A., Whitaker, J. D., \& Parker, L. (2012). Migration, distribution, and diving behavior of adult male loggerhead sea turtles (Caretta caretta) following dispersal from a major breeding aggregation in the Western North Atlantic. Marine Biology, 159(1), 113-125. https://doi.org/10.1007/s00227-011-1826-0

Berkson, H. (1966). Physiological adjustments to prolonged diving in the Pacific green turtle (Chelonia mydas agassizii). Comparative Biochemistry and Physiology, 18(1), 101-119.

Berkson, H. (1967). Physiological adjustments to deep diving in the Pacific green turtle (Chelonia mydas agassizzii). Comparative Biochemistry and Physiology, 21(3), 507524.

Bernardo, J., \& Plotkin, P. T. (2007). An evolutionary perspective on the arribada phenomenon and reproductive behavioral polymorphism of olive ridley sea turtles (Lepidochelys olivacea). In P. T. Plotkin (Ed.), Biology and Conservation of Ridley Sea Turtles (pp. 59-87). Baltimore: The Johns Hopkins University Press.

Bradshaw, C. J. A., McMahon, C. R., \& Hays, G. C. (2007). Behavioral Inference of Diving Metabolic Rate in Free-Ranging Leatherback Turtles. Physiological and Biochemical Zoology, 80(2), 209-219. https://doi.org/10.1086/511142

Butler, P. J. (2006). Aerobic dive limit. What is it and is it always used appropriately? Comparative Biochemistry and Physiology - A Molecular and Integrative Physiology, 145(1), 1-6. https://doi.org/10.1016/j.cbpa.2006.06.006

Ceriani, S. A., Weishampel, J. F., Ehrhart, L. M., Mansfield, K. L., \& Wunder, M. B. (2017). Foraging and recruitment hotspot dynamics for the largest Atlantic loggerhead turtle rookery. Scientific Reports, 7(1), 1-13. https://doi.org/10.1038/s41598-01717206-3 
Chambault, P., de Thoisy, B., Heerah, K., Conchon, A., Barrioz, S., Dos Reis, V., ... Chevallier, D. (2016). The influence of oceanographic features on the foraging behavior of the olive ridley sea turtle Lepidochelys olivacea along the Guiana coast. Progress in Oceanography, 142(February), 58-71. https://doi.org/10.1016/j.pocean.2016.01.006

Costa, D. P., Gales, N. J., \& Goebel, M. E. (2001). Aerobic dive limit: How often does it occur in nature? Comparative Biochemistry and Physiology - A Molecular and Integrative Physiology, 129(4), 771-783. https://doi.org/10.1016/S10956433(01)00346-4

Crawford, N. G., Parham, J. F., Sellas, A. B., Faircloth, B. C., Glenn, T. C., Papenfuss, T. J., ... Simison, W. B. (2015). A phylogenomic analysis of turtles. Molecular Phylogenetics and Evolution, 83, 250-257. https://doi.org/10.1016/j.ympev.2014.10.021

Davis, B. J. (1991). Developmental changes in the blood oxygen transport system of Kemp's ridley sea turtle, Lepidochelys kempi. Canadian Journal of Zoology, 69, 2660-2666.

Dodge, K. L., Galuardi, B., Miller, T. J., \& Lutcavage, M. E. (2014). Leatherback turtle movements, dive behavior, and habitat characteristics in ecoregions of the Northwest Atlantic Ocean. PLoS ONE, 9(3).

https://doi.org/10.1371/journal.pone.0091726

Dutton, P. H. (1996). Methods for collection and preservation of samples for sea turtle genetic studies. In B. W. Bowen \& W. N. Witzell (Eds.), Proceedings of the International Symposium (pp. 17-24). Miami, Florida. https://doi.org/10.1051/parasite/2014024

El-Sayed, H., Goodall, S. R., \& Hainsworth, R. (1995). Re-evaluation of Evans blue dye dilution method of plasma volume measurement. Clinical and Laboratory Haematology, 17(2), 189-194. Retrieved from http://www.ncbi.nlm.nih.gov/pubmed/8536425

Enstipp, M. R., Ciccione, S., Gineste, B., Milbergue, M., Ballorain, K., Ropert-Coudert, Y., ... Georges, J.-Y. (2011). Energy expenditure of freely swimming adult green turtles (Chelonia mydas) and its link with body acceleration. Journal of Experimental Biology, 214, 4010-4020. https://doi.org/10.1242/jeb.062943

Espinoza-Romo, B. A., Sainz-Hernández, J. C., Ley-Quiñónez, C. P., Hart, C. E., LealMoreno, R., Aguirre, A. A., \& Zavala-Norzagaray, A. A. (2018). Blood biochemistry of olive ridley (Lepidochelys olivacea) sea turtles foraging in northern Sinaloa, Mexico. PLoS ONE, 13(7), 1-12. https://doi.org/10.1371/journal.pone.0199825 
Foldager, N., \& Blomqvist, C. (1991). Repeated plasma volume determination with the Evans blue dye dilution technique: the method and a computer program. Comput Biol Med, 21, 35-41.

Gaos, A. R., Lewison, R. L., Wallace, B. P., Yañez, I. L., Liles, M. J., Nichols, W. J., ... Seminoff, J. A. (2012). Spatial ecology of critically endangered hawksbill turtles Eretmochelys imbricata: Implications for management and conservation. Marine Ecology Progress Series, 450, 181-194. https://doi.org/10.3354/meps09591

García-Párraga, D., Crespo-Picazo, J. L., Belnaldo De Quirós, Y., Cervera, V., MartíBonmati, L., Díaz-Delgado, J., ... Fernández, A. (2014). Decompression sickness ('the bends') in sea turtles. Diseases of Aquatic Organisms, 111(3), 191-205. https://doi.org/10.3354/dao02790

García-Párraga, D., Lorenzo, T., Wang, T., Ortiz, J.-L., Ortega, J., Crespo-Picazo, J.-L., ... Fahlman, A. (2018). Deciphering function of the pulmonary arterial sphincters in loggerhead sea turtles ( Caretta caretta ). The Journal of Experimental Biology, 221(23), 1-9. https://doi.org/10.1242/jeb.179820

Hawkes, L. A., Broderick, A. C., Godfrey, M. H., \& Godley, B. J. (2009). Climate change and marine turtles. Endangered Species Research, 7(2), 137-154. https://doi.org/10.3354/esr00198

Hays, G. C., Adams, C. R., Broderick, A. C., Godley, B. J., Lucas, D. J., Metcalfe, J. D., \& Prior, A. A. (2000). The diving behaviour of green turtles at Ascension Island. Animal Behaviour, 59(3), 577-586. https://doi.org/10.1006/anbe.1999.1326

Hays, G. C., \& Hawkes, L. A. (2018). Satellite Tracking Sea Turtles: Opportunities and Challenges to Address Key Questions. Frontiers in Marine Science, 5(November), 112. https://doi.org/10.3389/fmars.2018.00432

Hays, G. C., Hobson, V. J., Metcalfe, J. D., Righton, D., \& Sims, D. W. (2006). Flexible Foraging Movements of Leatherback Turtles across the North Atlantic Ocean. Ecology, 87(10), 2647-2656.

Hays, G. C., Metcalfe, J. D., \& Walne, A. W. (2004). The Implications of Lung-Regulated Buoyancy Control for Dive Depth and Duration. Ecology, 85(4), 1137-1145.

Heithaus, M. R. (2013). Predators, Prey, and the Ecological Roles of Sea Turtles. In J. Wyneken, K. J. Lohmann, \& J. A. Musick (Eds.), The Biology of Sea Turtles Volume III (pp. 249-284). Boca Raton, Florida: CRC Press. Taylor \& Francis Group. 
Hochscheid, S. (2014). Why we mind sea turtles' underwater business: A review on the study of diving behavior. Journal of Experimental Marine Biology and Ecology, 450, 118-136. https://doi.org/10.1016/j.jembe.2013.10.016

Hochscheid, S., Godley, B. J., Broderick, A. C., \& Wilson, R. P. (1999). Reptilian diving: Highly variable dive patterns in the green turtle Chelonia mydas. Marine Ecology Progress Series, 185, 101-112. https://doi.org/10.3354/meps185101

Hochscheid, S., McMahon, C. R., Bradshaw, C. J. A., Maffucci, F., Bentivegna, F., \& Hays, G. C. (2007). Allometric scaling of lung volume and its consequences for marine turtle diving performance. Comparative Biochemistry and Physiology - A Molecular and Integrative Physiology, 148(2), 360-367. https://doi.org/10.1016/j.cbpa.2007.05.010

Howell, E. A., Dutton, P. H., Polovina, J. J., Bailey, H., Parker, D. M., \& Balazs, G. H. (2010). Oceanographic influences on the dive behavior of juvenile loggerhead turtles (Caretta caretta) in the North Pacific Ocean. Marine Biology, 157(5), 10111026. https://doi.org/10.1007/s00227-009-1381-0

Hunt, K. E., Innis, C., Merigo, C., Burgess, E. A., Norton, T., Davis, D., ... Buck, C. L. (2019). Ameliorating transport-related stress in endangered Kemp's ridley sea turtles (Lepidochelys kempii) with a recovery period in saltwater pools. Conservation Physiology, 7(1), coy065. https://doi.org/10.1093/conphys/coy065

Keller, J. M., Kucklick, J. R., Stamper, M. A., Harms, C. A., \& McClellan-Green, P. D. (2004). Associations between organochlorine contaminant concentrations and clinical health parameters in loggerhead sea turtles from North Carolina, USA. Environmental Health Perspectives, 112(10), 1074-1079. https://doi.org/10.1289/ehp.6923

Kinoshita, C., Fukuoka, T., Niizuma, Y., Narazaki, T., \& Sato, K. (2018). High resting metabolic rates with low thermal dependence induce active dives in overwintering Pacific juvenile loggerhead turtles. The Journal of Experimental Biology, 221(13), jeb175836. https://doi.org/10.1242/jeb.175836

Kooyman, G. L. (1989). Diverse Divers: Physiology and Behavior. (W. Burggren, S. Ishii, H. Langer, G. Neuweiler, \& D. J. Randall, Eds.). Berlin: Springer-Verlag.

Lewbart, G. A., Hirschfeld, M., Denkinger, J., Vasco, K., Guevara, N., García, J., ... Lohmann, K. J. (2014). Blood gases, biochemistry, and hematology of galapagos green turtles (Chelonia mydas). PLOS ONE, 9(5), 1-7. https://doi.org/10.1371/journal.pone.0096487 
Lewison, R., Wallace, B., Alfaro-Shigueto, J., Mangel, J. C., Maxwell, S. M., \& Hazen, E. L. (2013). Fisheries Bycatch of Marine Turtles. In J. Wyneken, K. J. Lohmann, \& J. A. Musick (Eds.), The Biology of Sea Turtles Volume III (pp. 329-351). Boca Raton, Florida: CRC Press. Taylor \& Francis Group.

López-Mendilaharsu, M., Rocha, C. F. D., Domingo, A., Wallace, B. P., \& Miller, P. (2008). Prolonged, deep dives by the leatherback turtle Dermochelys coriacea: pushing their aerobic dive limits. Journal of the Marine Biological Association 2, 2(Figure 1), 1-3. https://doi.org/10.1017/S1755267208000390

Lutcavage, M. E., Bushnell, P. G., \& Jones, D. R. (1990). Oxygen Transport in the Leatherback Sea Turtle Dermochelys coriacea. Physiological Zoology, 63(5), 10121024.

Lutcavage, M. E., Bushnell, P. G., \& Jones, D. R. (1992). Oxygen stores and aerobic metabolism in the leatherback sea turtle. Canadian Journal of Zoology, 70, 348351.

Lutcavage, M. E., Lutz, P. L., \& Baier, H. (1989). Respiration mechanics of the loggerhead sea turtle, Caretta caretta. Respiration Physiology, 76, 13-24.

Lutz, P. L., \& Bentley, T. B. (1985). Respiratory Physiology of Diving in the Sea Turtle. Copeia, 3, 671-679.

Marquez-M, R. (1994). Synopsis of Biological Data on the Kemp ' s Ridley Turtle, Lepidochelys kempi (Garman, 1880). NOAA Technical Memorandum NMFS-SEFSC343.

McDonald, B. I., \& Ponganis, P. J. (2013). Insights from venous oxygen profiles : oxygen utilization and management in diving California sea lions. The Journal of Experimental Biology, 216(1), 3332-3341. https://doi.org/10.1242/jeb.085985

McMahon, C. R., Bradshaw, C. J. A., \& Hays, G. C. (2007). Satellite tracking reveals unusual diving characteristics for a marine reptile, the olive ridley turtle Lepidochelys olivacea. Marine Ecology Progress Series, 329, 239-252. https://doi.org/10.3354/meps329239

Mettee, N. (2014). Sample Collection Techniques. Retrieved from http://www.seaturtleguardian.org/sample-collection-techniques

Minamikawa, S., Naito, Y., Sato, K., Matsuzawa, Y., Bando, T., \& Sakamoto, W. (2000). Maintenance of neutral buoyancy by depth selection in the loggerhead turtle Caretta caretta. The Journal of Experimental Biology, 203, 2967-2975. Retrieved from http://www.ncbi.nlm.nih.gov/pubmed/10976033 
Muñoz-Pérez, J. P., Lewbart, G. A., Hirschfeld, M., Alarcón-Ruales, D., Denkinger, J., Guillermo Castañeda, J., ... Lohmann, K. J. (2017). Blood gases, biochemistry and haematology of Galápagos hawksbill turtles (Eretmochelys imbricata). Conservation Physiology, 5, 1-9.

Okuyama, J., Kataoka, K., Kobayashi, M., Abe, O., Yoseda, K., \& Arai, N. (2012). The regularity of dive performance in sea turtles: A new perspective from precise activity data. Animal Behaviour, 84(2), 349-359.

https://doi.org/10.1016/j.anbehav.2012.04.033

Poloczanska, E. S., Limpus, C. J., \& Hays, G. C. (2010). Vulnerability of marine turtles to climate change. In D. W. Sims (Ed.), Advances in Marine Biology (Vol. 56, pp. 151211). Burlington: Elsevier Ltd. https://doi.org/10.1016/S0065-2881(09)56002-6

Polovina, J. J., Balazs, G. H., Howell, E. A., Parker, D. M., Seki, M. P., \& Dutton, P. H. (2004). Forage and migration habitat of loggerhead (Caretta caretta) and olive ridley (Lepidochelys olivacea) sea turtles in the central North Pacific Ocean. Fisheries Oceanography, 13(1), 36-51.

Polovina, J. J., Howell, E. A., \& Balazs, G. H. (2003). Dive-depth distribution of loggerhead (Caretta caretta) and olive ridley (Lepidochelys olivacea) sea turtles in the central North Pacific: Might deep longline sets catch fewer turtles? Fishery Bulletin, 101(1), 189-193.

Polovina, J. J., Howell, E., Parker, D. M., \& Balazs, G. H. (2003). Dive-depth distribution of loggerhead (Carretta carretta) and olive ridley (Lepidochelys olivacea) sea turtles in the central North Pacific: Might deep longline sets catch fewer turtles? Fishery Bulletin, 101(1), 189-193.

Ponganis, P. J. (2011). Diving Mammals. Comprehensive Physiology, 1, 447-465. https://doi.org/10.1002/cphy.c091003

Ponganis, P. J., Meir, J. U., \& Williams, C. L. (2011). In pursuit of Irving and Scholander : a review of oxygen store management in seals and penguins. The Journal of Experimental Biology, 214, 3325-3339. https://doi.org/10.1242/jeb.031252

Ponganis, P. J., \& Williams, C. L. (2016). Oxygen stores and diving. In M. A. Castellini \& J.A. Mellish (Eds.), MARINE MAMMAL PHYSIOLOGY-Requisites for ocean living (pp. 29-46). Boca Raton, Florida: CRC Press. Taylor \& Francis Group.

Portugues, C., Crespo-Picazo, J. L., García-Párraga, D., Altimiras, J., Lorenzo, T., BorqueEspinosa, A., \& Fahlman, A. (2018). Impact of gas emboli and hyperbaric treatment on respiratory function of loggerhead sea turtles (Caretta caretta). Conservation Physiology, 6(1), 1-8. https://doi.org/10.1093/conphys/cox074 
Pritchard, P. C. H. (2007). Arribadas I Have Known. In P. T. Plotkin (Ed.), Biology and Conservation of Ridley Sea Turtles (pp. 7-22). Baltimore: Johns Hopkins University Press.

Ramirez Acevedo, L. M., Martinez Blas, S. S., \& Fuentes-Mascorro, G. (2012). Hemogram and Morphological Characteristics of Blood Cells in the Olive Ridley Turtle (Lepidochelys olivacea) of Oaxaca, Mexico. Revista Cientifica, 22(5), 468-476.

Richardson, P. B., Broderick, A. C., Coyne, M. S., Ekanayake, L., Kapurusinghe, T., Premakumara, C., ... Godley, B. J. (2013). Satellite telemetry reveals behavioural plasticity in a green turtle population nesting in Sri Lanka. Marine Biology, 160(6), 1415-1426. https://doi.org/10.1007/s00227-013-2194-8

Robinson, N. J., \& Paladino, F. V. (2015). Diving Behavior and Physiology of the Leatherback Turtle. In J. R. Spotila \& P. Santidrián Tomillo (Eds.), The Leatherback Turtle (pp. 21-31). Baltimore: Johns Hopkins University Press.

Rousselet, E., Levin, M., Gebhard, E., Higgins, B. M., DeGuise, S., \& Godard-Codding, C. A. J. (2013). Evaluation of immune functions in captive immature loggerhead sea turtles (Caretta caretta). Veterinary Immunology and Immunopathology, 156, 4353. https://doi.org/10.1016/j.vetimm.2013.09.004

Spotila, J. R. (2004). Sea turtles: A complete guide to their biology, behavior, and conservation. Sea turtles: A complete guide to their biology, behavior, and conservation. Baltimore: Johns Hopkins University Press.

Spotila, J. R., O'Connor, M. P., \& Paladino, F. V. (1996). Thermal Biology. In P. L. Lutz \& J. A. Musick (Eds.), The Biology of Sea Turtles (pp. 297-314). Boca Raton, Florida: CRC Press. Taylor \& Francis Group.

Stabenau, E. K., \& Heming, T. A. (1994). The in vitro respiratory and acid-base properties of blood and tissue from the Kemp's ridley sea turtle, Lepidochelys kempi. Canadian Journal of Zoology, 72, 1403-1408.

Stamper, M. A., Harms, C., Epperly, S. P., Braun-McNeill, J., Avens, L., \& Stoskopf, M. K. (2005). Relationship between barnacle epibiotic load and hematologic parameters in loggerhead sea turtles (Caretta caretta), a comparison between migratory and residential animals in Pamlico Sound, North Carolina. Journal of Zoo and Wildlife Medicine, 36(4), 635-641. https://doi.org/10.1638/04-074.1

Swimmer, Y., Arauz, R., McCracken, M., McNaughton, L., Ballestero, J., Musyl, M., ... Brill, R. (2006). Diving behavior and delayed mortality of olive ridley seat turtles Lepidochelys olivacea after their release from longline fishing gear. Marine Ecology Progress Series, 323, 253-261. https://doi.org/10.1109/94.993730 
Tenney, S. M., Bartlett, J., Farber, J. P., \& Remmers, J. E. (1974). Mechanics of the respiration cycle in the green turtle (Chelonia mydas). Respiration Physiology, 22, 361-368.

Thorson, T. B. (1968). Body Fluid Partitioning in Reptilia. Copeia, 3, 592-601.

Valverde, R. A., Orrego, C. M., Tordoir, M. T., Gómez, F. M., Solís, D. S., Hernández, R. A., Spotila, J. R. (2012). Olive Ridley Mass Nesting Ecology and Egg Harvest at Ostional Beach, Costa Rica. Chelonian Conservation and Biology, 11(1), 1-11. https://doi.org/10.2744/CCB-0959.1

Valverde, R. A., Owens, D. W., Mackenzie, D. S., \& Amoss, M. S. (1999). Basal and stressinduced corticosterone levels in olive ridley sea turtles (Lepidochelys olivacea) in relation to their mass nesting behavior. Journal of Experimental Zoology, 284(6), 652-662. https://doi.org/10.1002/(SICI)1097-010X(19991101)284:6<652::AIDJEZ7>3.0.CO;2-U

Wallace, B. P., DiMatteo, A. D., Bolten, A. B., Chaloupka, M. Y., Hutchinson, B. J., AbreuGrobois, F. A., ... Mast, R. B. (2011). Global conservation priorities for Marine turtles. PLOS ONE, 6(9). https://doi.org/10.1371/journal.pone.0024510

Wells, R. M., \& Baldwin, J. (1994). Oxygen Transport in Marine Green Turtle (chelonia Mydas) Hatchlings - blood Viscosity and control of Hemoglobin Oxygen- Affinity. Journal of Experimental Biology, 188, 103-114.

Williams, C. L., Meir, J. U., \& Ponganis, P. J. (2011). What triggers the aerobic dive limit ? Patterns of muscle oxygen depletion during dives of emperor penguins. The Journal of Experimental Biology, 214, 1802-1812. https://doi.org/10.1242/jeb.052233

Williams, C. L., Sato, K., \& Ponganis, P. J. (2019). Activity not submergence explains diving heart rates of captive loggerhead turtles. The Journal of Experimental Biology, 222, jeb.200824. https://doi.org/10.1242/jeb.200824

Williard, A. S. (2013). Physiology as Integrated Systems. In J. Wyneken, K. J. Lohmann, \& J. A. Musick (Eds.), The Biology of Sea Turtles Volume III (pp. 1-30). Boca Raton, Florida: CRC Press. Taylor \& Francis Group.

Wood, F. E., \& Ebanks, G. K. (1984). Blood Cytology and Hematology of the Green Sea Turtle, Chelonia mydas. Herpetologica, 40(3), 331-336.

Wood, S. C., Gatz, R. N., \& Glass, M. L. (1984). Oxygen transport in the green sea turtle. Journal of Comparative Physiology B, 154(3), 275-280.

https://doi.org/10.1007/BF02464407 
Work, T. M., \& Balazs, G. H. (1999). Relating Tumor Score to Hematology in Green Turtles with Fibropapillomatosis in Hawaii. Journal of Wildlife Diseases, 35(4), 804807. https://doi.org/10.7589/0090-3558-35.4.804

Yang, T., Haas, H. L., Patel, S., Smolowitz, R., James, M. C., \& Williard, A. S. (2019). Blood biochemistry and haematology of migrating loggerhead turtles (Caretta caretta) in the Northwest Atlantic: Reference intervals and intra-population comparisons. Conservation Physiology, 7(1), 1-15. https://doi.org/10.1093/conphys/coy079

Yasuda, T., \& Arai, N. (2009). Changes in flipper beat frequency, body angle and swimming speed of female green turtles Chelonia mydas. Marine Ecology Progress Series, 386, 275-286. https://doi.org/10.3354/meps08084 